\title{
APPLICATION OF MAJOR ION CONCENTRATIONS FOR THE PREDICTION OF STABLE ISOTOPIC COMPOSITION IN SURFACE WATER
}

\author{
Kai CHEN ${ }^{1,2}$, Linhua SUN ${ }^{1,2 *}$ \\ ${ }^{1}$ School of Resources and Civil Engineering, Suzhou University, Anhui, China \\ ${ }^{2}$ School of Earth and Environment, Anhui University of Science \& Technology, Anhui, China
}

Received 21 September 2020; accepted 27 November 2020

\author{
Highlights \\ $\delta^{2} \mathrm{H}$ and $\delta^{18} \mathrm{O}$ values are essential for the management of water resources. \\ Major ion concentrations and stable isotopic compositions of surface water were influenced by evaporation. \\ $\delta^{18} \mathrm{O}$ can be predicted by some major ions selected by optimal subset regression.
}

\begin{abstract}
The $\delta^{2} \mathrm{H}$ and $\delta^{18} \mathrm{O}$ values in water bodies are essential to the management of water resources because of the ability to insight into hydrological processes. In this study, we have measured and analyzed the major ions $\left(\mathrm{Na}^{+}, \mathrm{K}^{+}, \mathrm{Ca}^{2+}\right.$, $\mathrm{Mg}^{2+}, \mathrm{Cl}^{-}, \mathrm{SO}_{4}^{2-}$ and $\left.\mathrm{HCO}_{3}^{-}\right)$and stable $\mathrm{H}-\mathrm{O}$ isotopes $\left(\delta^{2} \mathrm{H}\right.$ and $\left.\delta^{18} \mathrm{O}\right)$ for fifteen surface water samples collected from the Xinbian River in Suzhou, northern Anhui Province, China. The results show that all of the water samples are classified to be $\mathrm{Na}-\mathrm{HCO}_{3}$ type, and the mean values of $\delta^{2} \mathrm{H}$ and $\delta^{18} \mathrm{O}$ are $-42.93 \%$ and $-5.36 \%$, respectively. Gibbs diagram and the relationship between $\delta^{2} \mathrm{H}$ and $\delta^{18} \mathrm{O}$ indicate that both water chemistry and stable isotopes in river water are mainly controlled by evaporation. Correlation analysis reveals that a significant correlation between major ions and $\delta^{18} \mathrm{O}$. Predictors $\left(\mathrm{K}^{+}, \mathrm{SO}_{4}^{2-}\right.$ and $\left.\mathrm{HCO}_{3}^{-}\right)$have been selected by optimal subset regression analysis were used to model the $\delta^{18} \mathrm{O}$ values in the river water. Moreover, the residuals of the model were normally distributed and values between $-0.2 \%$ to $0.2 \%$ for most water samples, suggesting a strong relationship between the observed and predicted $\delta^{18} \mathrm{O}$ values.
\end{abstract}

Keywords: major ions, stable isotopes, prediction, river water, hydrochemistry.

\section{Introduction}

Water is the most important resource for human survival and social development. However, in recent years, water pollution in many areas has become more seriously as a result of human activities, such as households, agriculture and industry (Wang \& Yang, 2016; Alam et al., 2020; Singh et al., 2020). Under this situation, the stable isotopes have gained more attention from researchers because it can be used to understand the hydrological processes in different watersheds (Kumar et al., 2019), the relationships between different water bodies (Qian et al., 2013; Zhang et al., 2015), water quality assessment (Brooks et al., 2014) and sources of water recharge (Qian et al., 2014; Prada et al., 2016; Cao et al., 2018; Kuang et al., 2019).

The global meteoric water line $\left(\mathrm{GMWL}, \delta^{2} \mathrm{H}=\right.$ $8 \times \delta^{18} \mathrm{O}+10$ ) has been proposed by Craig and has been commonly used to reveal the recharge and discharge mechanisms of water bodies (Craig, 1961). Previous study found that the relationship between $\delta^{2} \mathrm{H}$ and $\delta^{18} \mathrm{O}$ tends to deviate from the GWML in different regions due to a variety of factors, including climate, altitude, latitude, and etc., and thus, the national meteoric water lines (NMWL) were often used to explore precipitation patterns in different countries (Dansgaard, 1964; Gat, 1996). Over the last few decades, several studies have been carried out based on the analyses of water stable isotopes, and these findings have provided important guidance for the regional management of water resources (Jeff, 2015; Sun et al., 2016; Tran et al., 2019; Wet et al., 2020).

However, disappointingly, the related-information on stable isotopes in water is difficult to obtain due to the high cost of stable isotopic instruments, and therefore, the application of stable isotopes is still limited. Therefore, in

*Corresponding author. E-mail: Sunlinh@126.com 
recent years, scholars have constructed various predictive models based on these factors (Kumar et al., 2019; Kuang et al., 2019; Delavau et al., 2011; Terzer et al., 2013; Ogrinc et al., 2018). For example, a model was constructed by $\delta^{18} \mathrm{O}$, latitude and elevation, and the model residuals were used to reveal hydrological processes in different stretches of the Ganga basin (Kumar et al., 2019). The $\delta^{18} \mathrm{O}$-elevation relationships in the Yellow River source region and surrounding areas have been modeled, and the results have been applied for paleo-elevation reconstructions (Kuang et al., 2019). The precipitation $\delta^{18} \mathrm{O}$ values have been modeled using five parameters (longitude, latitude, altitude, precipitation and temperature) in Canadian, and the results have certain significance for promoting the research of climate variability and surface hydrology in remote areas (Delavau et al., 2011). A multivariate linear regression analysis was performed on the $\delta^{18} \mathrm{O}$, longitude, latitude and altitude of rainfall over the Sava River Basin, and the predicted $\delta^{18} \mathrm{O}$ values were further compared with the measured $\delta^{18} \mathrm{O}$ values in river water. The research results showed that spatial variability is the major controlling factor for the surface water isotope ratios in this area (Ogrinc et al., 2018).

In summary, most prediction models for isotopes rely on meteorological or geographic parameters currently. However, the relationship between major ions and stable isotopes has not received corresponding attention, which limits the ability of the stable isotopes for understanding hydrological processes. Therefore, fifteen surface water samples have been collected from the Xinbian River, Suzhou, northern Anhui Province, China, and the contents of major ions and stable $\mathrm{H}-\mathrm{O}$ isotopes have been measured and analyzed in order to obtain the following information: (1) the compositions of water chemistry and stable isotopes and their controlling factors, (2) the relationship between major ions and stable isotopes, and (3) application of major ions to predict $\delta 18 \mathrm{O}$ values in river water using multiple linear regression model.

\section{Materials and methods}

\subsection{Study area}

Suzhou $\left(33^{\circ} 18^{\prime}-34^{\circ} 38^{\prime} \mathrm{N}\right.$ and $\left.116^{\circ} 09^{\prime}-118^{\circ} 10^{\prime} \mathrm{E}\right)$ is located in the junction of Anhui, Jiangsu, Henan and Shandong provinces with the total administrative area of $9787 \mathrm{~km}^{2}$. The study area belongs to the warm temperate zone and semi-humid monsoon climate and is in a plain landform with elevation between $20 \mathrm{~m}$ and $30 \mathrm{~m}$. Temperatures in the region range from $-1{ }^{\circ} \mathrm{C}$ to $37{ }^{\circ} \mathrm{C}$, with a multiyear average temperature and relative humidity of $14^{\circ} \mathrm{C}$ and $70 \%$, respectively. The average annual precipitation is $830 \mathrm{~mm}$, and $60 \%$ of the annual precipitation is concentrated in the summer. In addition, October is a typical representative of the dry season in the study area, while surface water is rarely affected by the mixture of other water bodies, such as rainfall and groundwater (Chen et al., 2020). The Xinbian River, completed in 1970, is a tributary of the Huai River basin (Figure 1) and is also the largest man-made river in Suzhou at present, with a length of $128 \mathrm{~km}$, an average width of $100 \mathrm{~m}$ and a watershed area of about $6562 \mathrm{~km}^{2}$, it has played an important role in agricultural irrigation and navigation in the area.

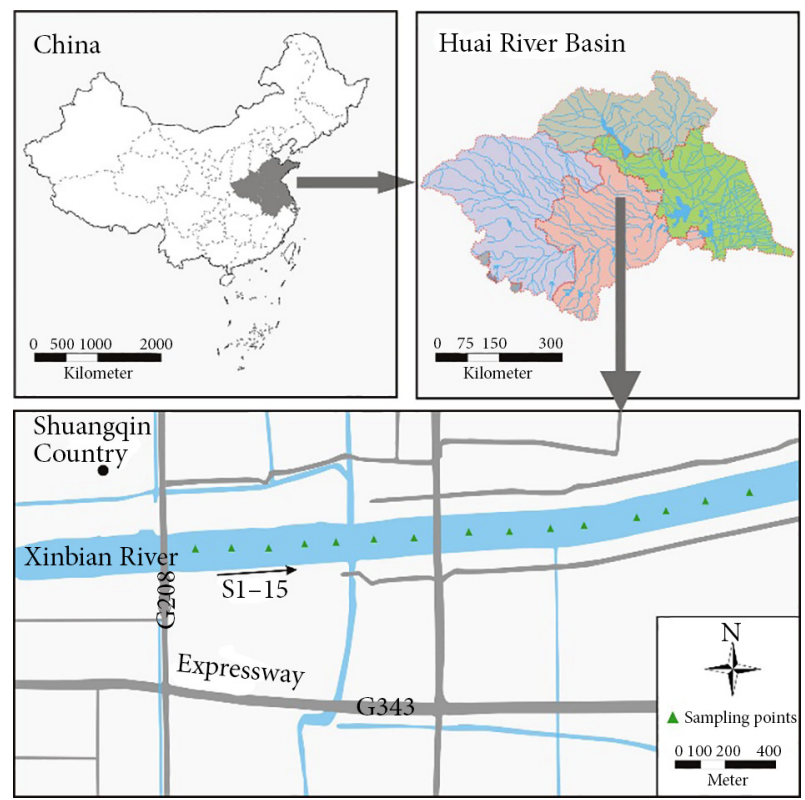

Figure 1. Location of the study area

\subsection{Sampling and analyses}

In this study, a total of fifteen surface water samples have been collected from the Xinbian River in October 2019, and the locations of the sampling points are shown in Figure 1. All river water samples were collected using precleaned polyethylene bottles at $50 \mathrm{~cm}$ below the water surface. After sampling, the samples were filtered through $0.45 \mu \mathrm{m}$ membranes in the laboratory and then stored at a constant temperature $\left(4^{\circ} \mathrm{C}\right)$ in the refrigerator. The major ions $\left(\mathrm{Na}^{+}, \mathrm{K}^{+}, \mathrm{Ca}^{2+}, \mathrm{Mg}^{2+}, \mathrm{Cl}^{-}\right.$and $\left.\mathrm{SO}_{4}^{2-}\right)$ were measured by ion chromatographs (ICS-600-900, Thermo Fischer Scientific, USA), and $\mathrm{HCO}_{3}^{-}$was measured by titration with hydrochloric acid at a concentration of $0.049 \mathrm{~mol} / \mathrm{l}$, ${ }^{2} \mathrm{H}$ and ${ }^{18} \mathrm{O}$ were measured by liquid phase isotope analyzer (LGR, LICA United Technology Limited, CAN) and the analytical results were expressed in $\delta$-notation (\%o) relative to the Vienna Standard Mean Ocean Water (V-SMOW). Furthermore, the measurement accuracies are $\pm 0.1 \%$ and $\pm 0.5 \%$ or for $\delta^{18} \mathrm{O}$ and $\delta^{2} \mathrm{H}$, respectively. Each parameter of each water sample was tested five times, then the maximum and minimum values were removed and the average of the three remaining values was taken as the final test result. The analysis of $\mathrm{HCO}^{-}$has been completed within 24 hours, and the analyses of other parameters have been completed within a week. For the data analysis, the Minitab (version 14), AqQA (version 1.5) and Rstudio (version 3.6.3, based on the ggplot2 package) had been used. 


\section{Results and discussions}

\subsection{Contents of the major ions and stable isotopes}

The analytical results for major ions and stable isotopes of water samples are shown in Table 1 and Figure 2. As shown in Figure 2a, the mean contents of $\mathrm{Cl}^{-}, \mathrm{Ca}^{2+}, \mathrm{Mg}^{2+}$ and $\mathrm{K}^{+}$are lower than the mean contents of $\mathrm{Na}^{+}, \mathrm{SO}_{4}{ }^{2-}$ and $\mathrm{HCO}_{3}^{-} . \mathrm{HCO}_{3}^{-}$has the highest average concentration, whereas $\mathrm{Na}^{+}$and $\mathrm{SO}_{4}^{2-}$ have similar average concentrations. The decreasing order of the mean concentrations of all ions are: $\mathrm{HCO}_{3}^{-}(308.6 \mathrm{mg} / \mathrm{L})>\mathrm{SO}_{4}^{2-}(175.4 \mathrm{mg} / \mathrm{L})$ $>\mathrm{Na}^{+}(156.2 \mathrm{mg} / \mathrm{L})>\mathrm{Cl}^{-}(121 \mathrm{mg} / \mathrm{L})>\mathrm{Mg}^{2+}(44.9 \mathrm{mg} / \mathrm{L})$
$>\mathrm{K}^{+}(24.5 \mathrm{mg} / \mathrm{L})>\mathrm{Ca}^{2+}(17 \mathrm{mg} / \mathrm{L})$. The $\delta^{2} \mathrm{H}$ values range from -44.85 to $-41.67 \%$, with a mean value of $-42.93 \%$. The $\delta^{18} \mathrm{O}$ values range from -5.94 to $-5.03 \%$, with mean value of $-5.36 \%$. In addition, the content of TDS ranges from 641.4 to $770.5 \mathrm{mg} / \mathrm{L}($ mean $=693.2 \mathrm{mg} / \mathrm{L})$, belonging to freshwater (TDS $<1000 \mathrm{mg} / \mathrm{L}$ ) (Table 1). As shown in Figure $2 \mathrm{~b}$, along the flow direction, $\mathrm{HCO}_{3}^{-}$content has an obvious upward and downward trend, $\mathrm{SO}_{4}^{2-}$ and $\mathrm{Cl}^{-}$contents show a decreasing trend, while the concentrations of $\mathrm{Na}^{+}, \mathrm{Mg}^{2+}, \mathrm{Ca}^{2+}$ and $\mathrm{K}^{+}$have no significant change characteristics.

Previous studies have shown that the flow of water from the recharge zone to the discharge zone is accompanied by
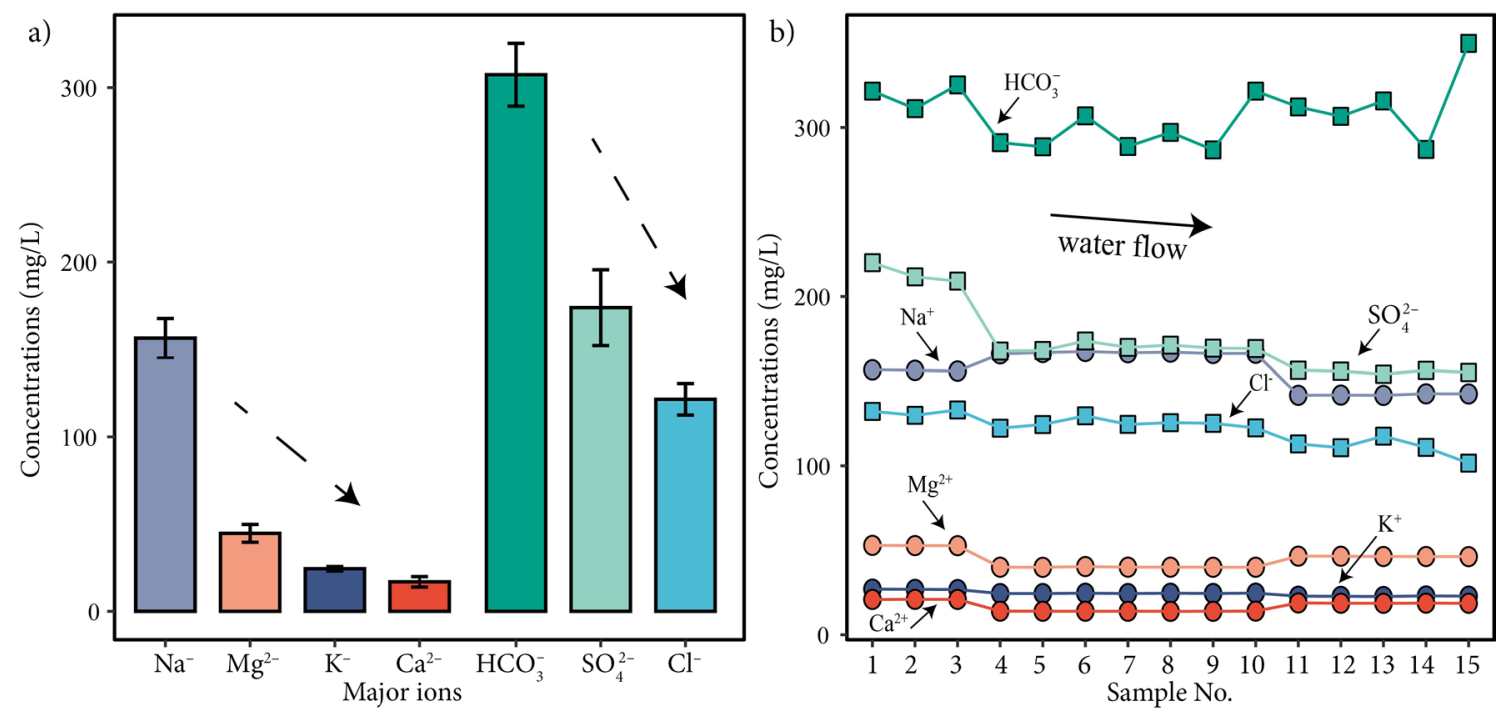

Figure 2. Major ion concentrations of water samples from Xinbian River, Suzhou, northern Anhui Province: $\mathrm{a}$ - Barplot of the major ion concentrations; $\mathrm{b}$ - Trends in the concentration of major ions in water along the flow direction

Table 1. Compositions of major ions $(\mathrm{mg} / \mathrm{L})$ and hydrogen and stable isotopes in river water

\begin{tabular}{|c|c|c|c|c|c|c|c|c|c|c|c|}
\hline \multirow{2}{*}{ ID } & $\mathrm{Na}^{+}$ & $\mathrm{K}^{+}$ & $\mathrm{Mg}^{2+}$ & $\mathrm{Ca}^{2+}$ & $\mathrm{Cl}^{-}$ & $\mathrm{SO}_{4}{ }^{2-}$ & $\mathrm{HCO}_{3}^{-}$ & TDS & $\delta^{2} \mathrm{H}$ & $\delta^{18} \mathrm{O}$ & d-excess \\
\hline & \multicolumn{8}{|c|}{ Unit: mg/L } & \multicolumn{3}{|c|}{ Unit: \%o } \\
\hline S1 & 156.7 & 27.0 & 52.9 & 20.9 & 132.2 & 220.0 & 321.6 & 770.5 & -42.25 & -5.47 & 1.48 \\
\hline S2 & 156.4 & 26.9 & 52.8 & 21.0 & 129.9 & 211.6 & 311.2 & 754.1 & -43.87 & -5.26 & -1.80 \\
\hline S3 & 156.0 & 26.8 & 52.7 & 20.9 & 133.1 & 209.1 & 325.2 & 761.1 & -43.54 & -5.49 & 0.39 \\
\hline S4 & 166.0 & 24.4 & 40.0 & 14.0 & 122.3 & 167.7 & 291.1 & 679.9 & -44.85 & -5.04 & -4.52 \\
\hline S5 & 166.8 & 24.4 & 39.9 & 13.9 & 124.5 & 168.0 & 288.6 & 681.9 & -42.79 & -5.06 & -2.32 \\
\hline S6 & 167.4 & 24.6 & 40.4 & 13.9 & 129.6 & 173.6 & 306.9 & 703.0 & -43.59 & -5.09 & -2.86 \\
\hline S7 & 166.7 & 24.4 & 40.0 & 13.9 & 124.5 & 169.9 & 288.8 & 683.8 & -41.97 & -5.28 & 0.24 \\
\hline S8 & 167.0 & 24.6 & 40.0 & 13.9 & 125.5 & 171.2 & 297.2 & 690.9 & -42.82 & -5.25 & -0.84 \\
\hline S9 & 166.2 & 24.5 & 40.0 & 13.9 & 125.1 & 169.4 & 286.8 & 682.5 & -43.29 & -5.23 & -1.45 \\
\hline S10 & 166.4 & 24.7 & 40.0 & 14.0 & 122.5 & 169.2 & 321.6 & 697.4 & -42.57 & -5.03 & -2.31 \\
\hline S11 & 141.7 & 22.8 & 46.5 & 18.8 & 112.9 & 156.5 & 312.2 & 655.5 & -41.67 & -5.71 & 4.02 \\
\hline S12 & 141.8 & 22.7 & 46.5 & 18.7 & 110.7 & 155.9 & 306.6 & 649.7 & -43.04 & -5.32 & -0.48 \\
\hline S13 & 141.7 & 22.7 & 46.3 & 18.6 & 117.6 & 154.1 & 315.8 & 658.8 & -41.75 & -5.73 & 4.05 \\
\hline S14 & 142.6 & 23.0 & 46.3 & 18.7 & 110.9 & 156.4 & 287.0 & 641.4 & -43.46 & -5.18 & -2.01 \\
\hline S15 & 142.5 & 22.9 & 46.2 & 18.6 & 101.6 & 155.2 & 349.8 & 662.0 & -41.79 & -5.94 & 5.74 \\
\hline
\end{tabular}




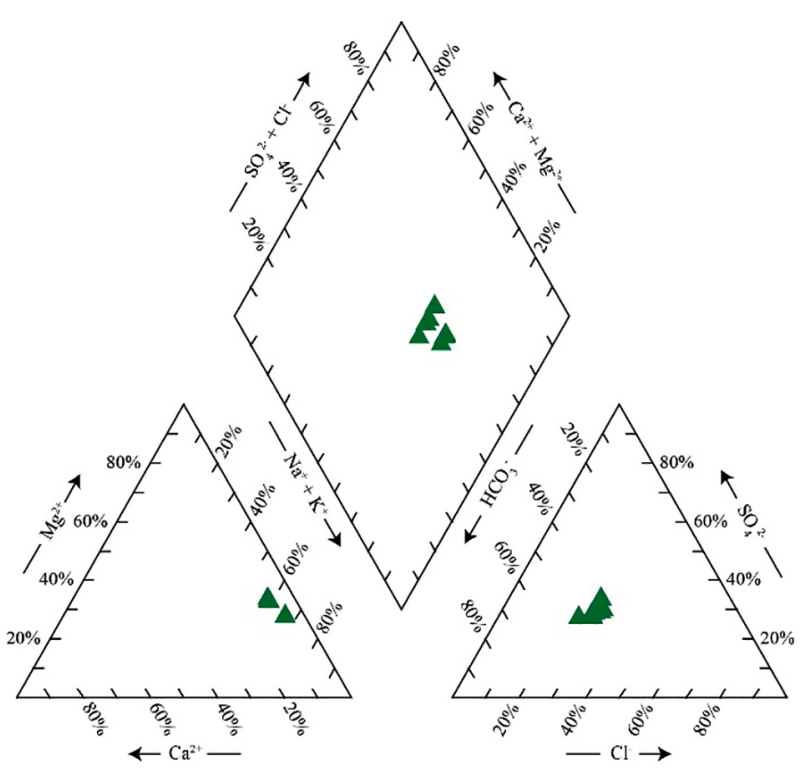

Figure 3. Piper diagram

a corresponding change in its major anion (from $\mathrm{HCO}_{3}^{-}$, $\mathrm{Cl}^{-}$to $\mathrm{SO}_{4}^{2-}$ ) (Tóth, 1999; Jalali, 2005). Therefore, classification of hydrochemistry types is essential to understand the evolution of water. In this study, Piper diagram have been used by AqQA software (version 1.5) for classifying hydrochemical types and the results are shown in Figure 3 (Piper, 1944). It can be seen that the cations and anions in all water samples show an enrichment trend towards $\mathrm{Na}^{+}$ and $\mathrm{HCO}_{3}^{-}$, respectively (Figure 3 ). Therefore, all of the river water samples were classified to be $\mathrm{Na}-\mathrm{HCO}_{3}^{-}$type, which means that the water is under the situation of sufficient recharge.

\subsection{Process controlling water chemistry and stable isotopes}

Gibbs diagram has been proposed by Gibbs and can be used to reveal the controlling mechanisms of surface water chemistry (Gibbs, 1970; Prasanna et al., 2011; Tiri et al., 2018; He \& Li, 2019). The three regions in Gibbs

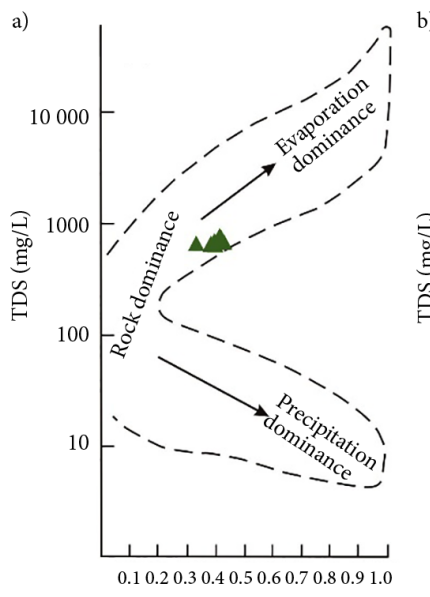

Gibbs I

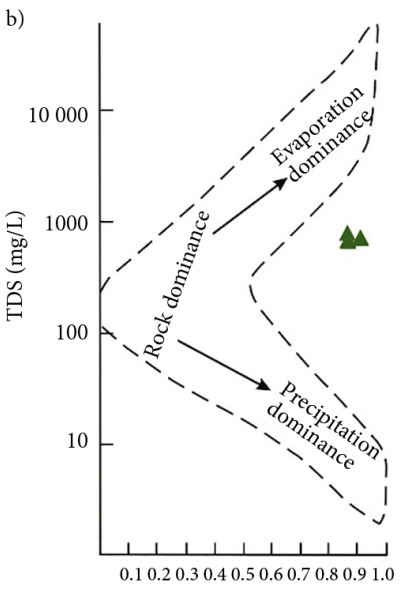

Gibbs II
Figure 4. Gibbs diagram diagram correspond to three different controlling mechanisms: evaporation dominance, rock dominance and precipitation dominance (see Figure 4). The calculations of the Gibbs values are: Gibbs $\mathrm{I}=\mathrm{Cl}^{-} /\left(\mathrm{Cl}^{-}+\mathrm{HCO}_{3}^{-}\right.$ ) and Gibbs II $=\mathrm{Na}^{+} /\left(\mathrm{Na}^{+}+\mathrm{Ca}^{2+}\right)$ (unit in meq/l). In this study, the Gibbs I values range from 0.33 to 0.42 and Gibbs II values range from 0.87 to 0.91 . It can be seen from the Figure $4 \mathrm{a}$ that all of the samples were located in the evaporation dominance area. In addition, previous studies have shown that evaporation will change the dominate cation in surface water from $\mathrm{Ca}^{2+}$ to $\mathrm{Na}^{+}$. As can be seen from the Figure $4 \mathrm{~b}$, all of the river water samples have high Gibbs II values (mean $=0.89$ ), implying that the water chemistry have been influenced by evaporation (Gibbs, 1970).

Previous studies have shown that evaporation line (EL) is an important reference for understanding the evaporation of regional water bodies (Chen et al., 2008). In recent years, most scholars have applied a combination of GMWL, NMWL and EL to study the relationship between stable isotopes in the water bodies and provided valuable guidance for regional water management (Kumar et al., 2019; Cao et al., 2018). In this study, due to the lack of rainfall-related data of Suzhou City, the GMWL, NMWL of China $\left(\delta^{2} \mathrm{H}=\right.$ $\left.7.89 \times \delta^{18} \mathrm{O}+8.16\right)$ and MEL (evaporation line in mining area near the study area, $\delta^{2} \mathrm{H}=5.89 \times \delta^{18} \mathrm{O}-7.68$ ) have been employed for understanding the mechanisms controlling the stable isotopes in river water (Chen et al., 2008; Zheng et al., 1983). As can be seen from the Figure 5, the relationship between $\delta^{2} \mathrm{H}$ and $\delta^{18} \mathrm{O}$ in this study is similar to MEL, but different from the GMWL and NMWL, and therefore, it can be inferred that the river water has been influenced by evaporation significantly.

The fractionation of stable isotopes in regional water bodies can be quantified by comparison with the d-excess values $\left(\delta^{2} \mathrm{H}-8 \times \delta^{18} \mathrm{O}\right)$ of GWML and NWML (Dansgaard, 1964). Previous studies have shown that water-rock interactions and evaporation are the major factors influencing the enrichment of $\delta^{2} \mathrm{H}$ and $\delta^{18} \mathrm{O}$ values in water bodies (Zhang et al., 2015). The embankments and bottom of this

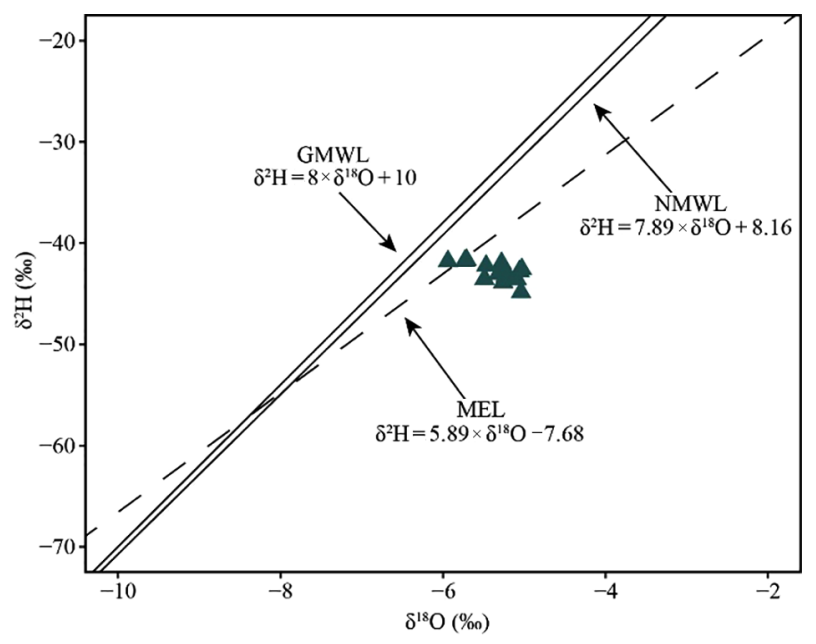

Figure 5. Relationships between $\delta^{2} \mathrm{H}$ and $\delta^{18} \mathrm{O}$ in river water 
section of the Xinbian River were artificially constructed with little contact with rocks and minerals, moreover, a very weak relationship with groundwater recharge (Chen et al., 2020). Therefore, in this study, the influence of $\delta^{2} \mathrm{H}$ and $\delta^{18} \mathrm{O}$ from water-rock interactions is limited. Because of the atomic mass of oxygen isotopes is much heavier than that of hydrogen isotopes, with the continues of evaporation, the fractionation of oxygen isotopes will be more significant than that of hydrogen isotopes, which will lead to the decreasing of d-excess value of surface water. In this study, the d-excess values of the fifteen water samples range from -4.52 to $5.74 \%$ o (mean $=-0.18 \%$ ), which were significantly lower than the d-excess value of GMWL (10\%o) and NMWL (8.16\%o), and suggesting that isotopic compositions of the river water have been strongly influenced by evaporation (Figure 6).

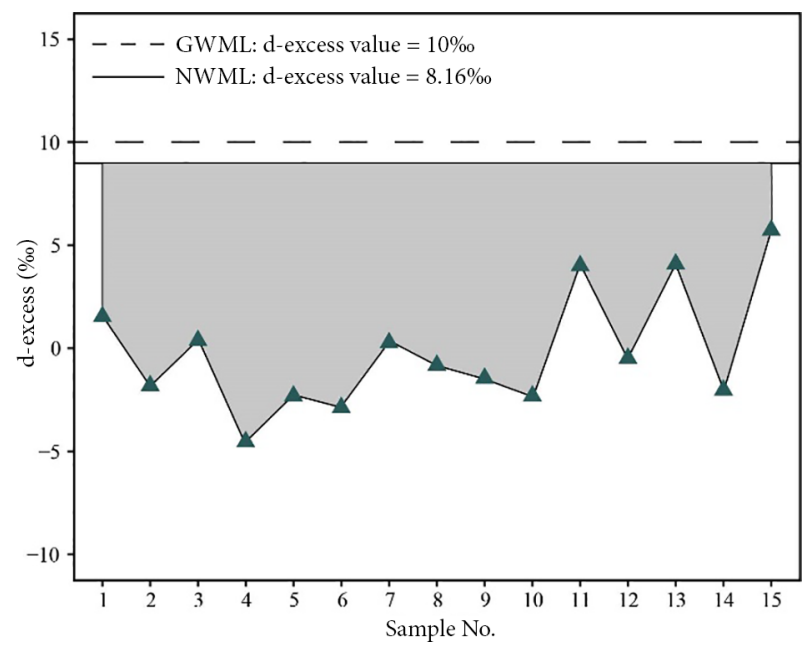

Figure 6. Variation of the d-excess for each water sample

\subsection{Relationship between major ions and stable isotopes}

Correlation analysis is a multivariate statistical analysis method, which can be used to evaluate the degree of intrinsic association between two or more variables ( $\mathrm{Wu}$ et al., 2014, 2020). In the study of geochemistry, a good correlation between elements means that they come from the same source or have been influenced by similar factors (Nwankwoala et al., 2014).

It can be seen from Tabel 2 that the $\delta^{18} \mathrm{O}$ has a significant positive correlation with $\mathrm{Na}^{+}(\mathrm{r}=0.722)$, and has a significant negative correlation with $\mathrm{HCO}_{3}^{-}(\mathrm{r}=-0.693)$ and $\mathrm{Ca}^{2+}(\mathrm{r}=-0.605)$, implying the close relationship between them. However, the relationship between hydrogen isotopes and major ions is insignificant, which was similar to the results obtained by the analysis of d-excess, because the mass of hydrogen isotope is lower than the oxygen isotope, and during the high extent of evaporation, the fractionation of hydrogen isotope will be insignificant. Such results provide the possibility of prediction of $\delta^{18} \mathrm{O}$ values by the major ion concentrations, but cannot be applied for the prediction of hydrogen isotopes (see below).

\subsection{Construction of prediction model}

\subsubsection{Major ion selection by optimal subset method}

Optimal subset regression is an effective tool for selecting linear regression models with as few variables as possible while ensuring a high degree of fit (Gorman, 1976; Lee et al., 2018). Based on the input dependent variable and multiple independent variables, best subset regression can generate several linear models. Then, it is necessary to select the optimal variables by artificially comparing the goodness-of-fit indexes in each model.

Table 3. Results of the optimal subset regression analysis

\begin{tabular}{|c|c|c|c|c|c|}
\hline $\begin{array}{r}\text { Mo- } \\
\text { del }\end{array}$ & $\mathrm{R}^{2}$ & $\mathrm{R}_{\text {adj }}^{2}$ & $\begin{array}{c}\text { Mallows } \\
\mathrm{C}_{\mathrm{p}}\end{array}$ & $\mathrm{S}$ & Predictor(s) \\
\hline 1 & 0.521 & 0.484 & 5.7 & 0.19853 & $\mathrm{X} 1$ \\
\hline 2 & 0.701 & 0.651 & 1.4 & 0.16318 & $\mathrm{X} 1, \mathrm{X} 7$ \\
\hline 3 & 0.740 & 0.669 & 2.1 & 0.15899 & $\mathrm{X} 2, \mathrm{X} 6, \mathrm{X} 7$ \\
\hline 4 & 0.748 & 0.647 & 3.8 & 0.16420 & $\mathrm{X} 1, \mathrm{X} 2, \mathrm{X} 4, \mathrm{X} 7$ \\
\hline 5 & 0.775 & 0.650 & 4.8 & 0.16342 & $\mathrm{X} 1, \mathrm{X} 2, \mathrm{X} 4, \mathrm{X} 6, \mathrm{X} 7$ \\
\hline 6 & 0.790 & 0.633 & 6.3 & 0.16743 & $\begin{array}{c}\mathrm{X} 1, \mathrm{X} 2, \mathrm{X} 3, \mathrm{X} 4, \mathrm{X} 6, \\
\mathrm{X} 7\end{array}$ \\
\hline 7 & 0.800 & 0.599 & 8.0 & 0.17499 & $\begin{array}{r}\mathrm{X} 1, \mathrm{X} 2, \mathrm{X} 3, \mathrm{X} 4, \mathrm{X} 5, \\
\mathrm{X} 6, \mathrm{X} 7\end{array}$ \\
\hline
\end{tabular}

Table 2. Results of correlation analysis

\begin{tabular}{|c|c|c|c|c|c|c|c|c|c|}
\hline & $\mathrm{Na}^{+}$ & $\mathrm{K}^{+}$ & $\mathrm{Mg}^{2+}$ & $\mathrm{Ca}^{2+}$ & $\mathrm{Cl}^{-}$ & $\mathrm{SO}_{4}^{2-}$ & $\mathrm{HCO}_{3}^{-}$ & $\delta^{2} \mathrm{H}$ & $\delta^{18} \mathrm{O}$ \\
\hline $\mathrm{Na}^{+}$ & 1.000 & & & & & & & & \\
\hline $\mathrm{K}^{+}$ & $0.514^{*}$ & 1.000 & & & & & & & \\
\hline $\mathrm{Mg}^{2+}$ & $-0.570^{\star}$ & 0.411 & 1.000 & & & & & & \\
\hline $\mathrm{Ca}^{2+}$ & $-0.724^{\star *}$ & 0.219 & $0.979^{\star *}$ & 1.000 & & & & & \\
\hline $\mathrm{Cl}^{-}$ & $0.708^{\star *}$ & $0.860^{* *}$ & 0.080 & -0.112 & 1.000 & & & & \\
\hline $\mathrm{SO}_{4}^{2-}$ & 0.300 & $0.969^{\star *}$ & $0.610^{*}$ & 0.437 & $0.774^{\star *}$ & 1.000 & & & \\
\hline $\mathrm{HCO}_{3}^{-}$ & -0.429 & 0.082 & $0.528^{\star}$ & $0.548^{\star}$ & -0.234 & 0.199 & 1.000 & & \\
\hline$\delta^{2} \mathrm{H}$ & -0.388 & -0.362 & 0.065 & 0.150 & -0.373 & -0.268 & 0.405 & 1.000 & \\
\hline$\delta^{18} \mathrm{O}$ & $0.722^{* *}$ & 0.275 & -0.511 & $-0.605^{*}$ & 0.476 & 0.096 & $-0.693^{\star *}$ & $-0.659^{\star *}$ & 1.000 \\
\hline
\end{tabular}

Note: ${ }^{*}$ and ${ }^{* *}$ represent significant correlations at the levels of 0.05 and 0.01 , respectively. 
In most studies, $\mathrm{R}^{2}, \mathrm{R}_{\text {adj }}^{2}$, Mallows $\mathrm{C}_{\mathrm{p}}$ and $\mathrm{S}$ are often used as reference indexes for selecting the best variables (Ke et al., 2009; Sun et al., 2010). The details of the four indicators are as follows: $\mathrm{R}^{2}$ is a goodness-of-fit indicator for the model, with values ranging from 0 to 1 . In general, a larger value of $\mathrm{R}^{2}$ indicating a better fit. However, even though some variables may be redundant, $\mathrm{R}^{2}$ still increases as the number of variables increases, which may lead to overfitting of the model. Therefore, $\mathrm{R}_{\text {adj }}^{2}$ is proposed to control the number of parameters in order to optimize the model. Mallows $\mathrm{C}_{\mathrm{p}}$ has been proposed by Mallows and is often used to evaluate the superiority of different linear regression models. The smaller its value, the more accurate the model is. $S$ is the root value of mean squared error for the model, the smaller the value, the smaller the difference between the predicted and observed values. The formulas for the four indicators are as follows:

$$
\begin{aligned}
& \mathrm{R}^{2}=1 \text { - SSE / SST; } \\
& \mathrm{R}_{\text {adj }}^{2}=1 \text { - MSE / [SST/(n - k)], }
\end{aligned}
$$

where SSE is the sum of squared errors, SST is the sum of squared total, MSE is the mean square error, $\mathrm{n}$ is the total number of samples and $\mathrm{k}$ is the number of selected predictors.

$$
\begin{aligned}
& \text { Mallow } \mathrm{C}_{\mathrm{p}}=\mathrm{SSE}_{\mathrm{p}} / \mathrm{MSE}_{\mathrm{m}}-(\mathrm{n}-2 \mathrm{p}) \\
& \mathrm{S}=(\mathrm{MSE})^{1 / 2},
\end{aligned}
$$

where $\mathrm{SSE}_{\mathrm{p}}$ is the sum of squared errors for the model under consideration, $p$ is the number of terms in the model (including constant) and $\mathrm{MSE}_{\mathrm{m}}$ is the mean square error for the model with all predictors.

The results of the optimal subset regression analysis are shown in Table 3 (Note: X1, X2, X3, X4, X5, X6 and $\mathrm{X} 7$ represent $\mathrm{Na}^{+}, \mathrm{K}^{+}, \mathrm{Mg}^{2+}, \mathrm{Ca}^{2+}, \mathrm{Cl}^{-}, \mathrm{SO}_{4}^{2-}$, and $\mathrm{HCO}_{3}^{-}$, respectively.). As can be seen in the table, from Model 1 to Model 3, R2adj increases gradually as the number of variables increases, while its value begins to decrease when

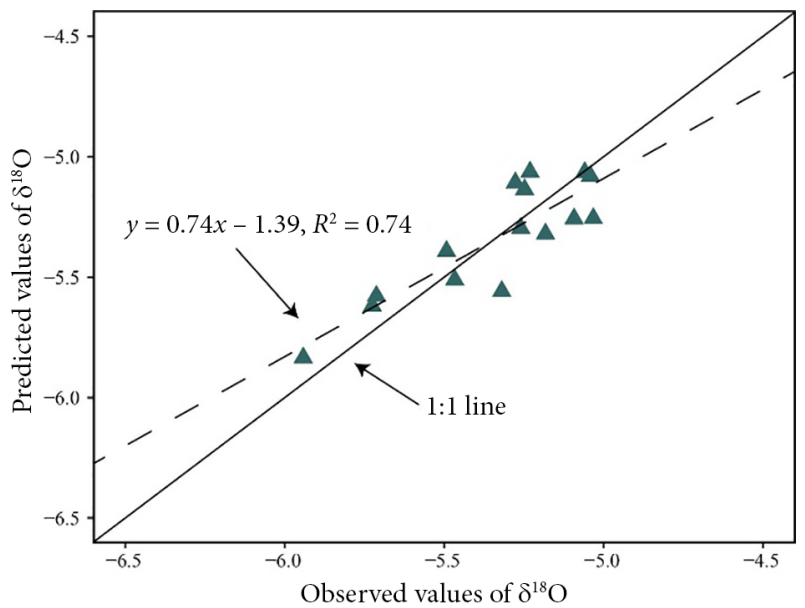

Figure 7. Relationships between observed values and predicted values of $\delta^{18} \mathrm{O}$ the number of variables increases to four or more, which is a signal that the model is beginning to overfit. At meanwhile, relative to Model 1 and Model 2, Model 3 has the highest $\mathrm{R}^{2}$ (value $\left.=0.74\right), \mathrm{R}_{\mathrm{adj}}^{2} \quad($ value $=0.669)$ and lowest $\mathrm{S}$ (value $=0.15899$ ). Thus, $\mathrm{K}^{+}, \mathrm{SO}_{4}^{2-}$ and $\mathrm{HCO}_{3}^{-}$were selected for the final linear fitting.

\subsubsection{Model construction \& residual analysis}

In summary, the concentrations of $\mathrm{K}^{+}, \mathrm{SO}_{4}^{2-}$ and $\mathrm{HCO}_{3}^{-}$were selected as predictors for the prediction of $\delta^{18} \mathrm{O}$. Then, the multiple linear regression was used, and the following equations was obtained:

$$
\begin{aligned}
& \delta^{18} \mathrm{O}=0.3771 \times\left(\mathrm{K}^{+}\right)-0.022681 \times\left(\mathrm{SO}_{4}^{2-}\right)- \\
& 0.007763 \times\left(\mathrm{HCO}_{3}^{-}\right)-8.219, \mathrm{R}^{2}=0.74 .
\end{aligned}
$$

It can be seen from Figure 7 that the fitting lines $(y=$ $0.74 x-1.39, \mathrm{R}^{2}=0.74$ ) have a high degree of coincidence with the 1:1 line $(y=x)$, with only a slight skew. In addition, most of the water samples were distributed near the 1:1 line and fitting line with litter deviation. The difference between the observed and predicted values of $\delta^{18} \mathrm{O}$ for each sample can be seen in Figure 8, and the high degree of similarity between the observed and predicted $\delta^{18} \mathrm{O}$ values further indicates the good fit of the models. Moreover, the residuals should be analyzed to check if the model violates any regression assumptions (Sun et al., 2010).

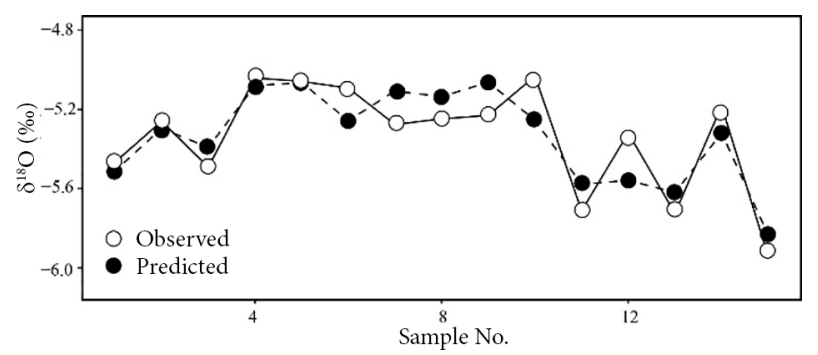

Figure 8 . The difference between observed values and predicted values of $\delta^{18} \mathrm{O}$ for each sample

The residual value was calculated by subtracting the predicted value from the observed value, and the statistics results can be seen in Figure 9. The Q-Q plot of the residuals was often used to test whether it was normally distributed. a)

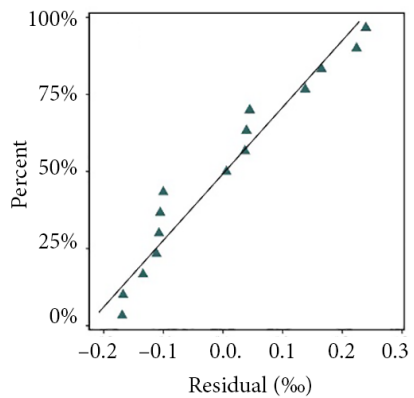

b)

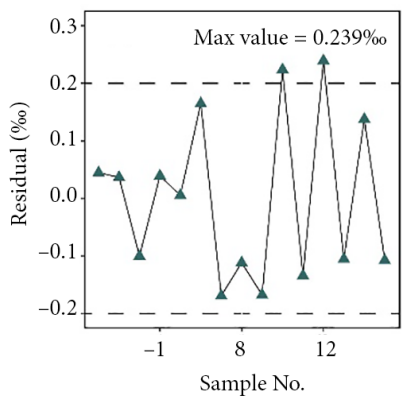

Figure 9. Results of the residual analysis: a - Q-Q plot of the residual values; b - Residual value for each sample 
In the Q-Q plot, the presence of severely deviated points indicates that the model violates the assumption of normal distribution. Figure 9a shows that all of the points approximately form a straight line. Therefore, it can be concluded that the model was consistent with the least squares hypothesis. Furthermore, as can be seen in Figure 9b, the maximum value of the residual was $0.239 \%$, and $81 \%$ of the samples (except sample 10 and 12) have residuals between $-0.2 \%$ and $0.2 \%$, an indication that the strong correlations between observed and predicted values.

\section{Conclusions}

Based on the analyses of the major ion concentrations and stable $\mathrm{H}-\mathrm{O}$ isotope contents of fifteen river water samples in Suzhou, northern Anhui Province, China, the following conclusions were obtained:

(1) The density distribution plot indicated that $\mathrm{Na}^{+}$ and $\mathrm{HCO}_{3}^{-}$were the dominant cation and anion, with average concentrations of $308.6 \mathrm{mg} / \mathrm{L}$ and $156.2 \mathrm{mg} / \mathrm{L}$, respectively, and all of the river water samples were classified to be $\mathrm{Na}-\mathrm{HCO}_{3}$ type. The mean values of $\delta^{2} \mathrm{H}$ and $\delta^{18} \mathrm{O}$ were $-42.93 \%$ and $-5.36 \%$, respectively.

(2) Gibbs diagram, the relationship between $\delta^{2} \mathrm{H}$ and $\delta^{18} \mathrm{O}$ and $\mathrm{d}$-excess show that evaporation is the major process controlling water chemistry and stable isotopes in river water. Moreover, the close relationship between major ions and $\delta^{18} \mathrm{O}$ were determined by correlation analysis.

(3) Q-Q plot indicated that the residuals of the model were normally distributed. The difference between the observed and predicted values for most water samples was between $-0.2 \%$ and $0.2 \%$, suggesting the strong relationships between them.

\section{References}

Alam, M. S., Han, B. S., Mizan, A., \& Pichtel, J. (2020). Assessment of soil and groundwater contamination at a former tannery district in Dhaka, Bangladesh. Environmental Geochemistry and Health, 42(7), 1905-1920.

https://doi.org/10.1007/s10653-019-00457-6

Brooks, J. R., Gibson, J. J., Birks, S. J., Weber, M. H., Rodecap, K. D., \& Stoddard, J. L. (2014). Stable isotope estimates of evaporation: inflow and water residence time for lakes across the United States as a tool for national lake water quality assessments. Limnology and Oceanography, 59(6), 2150-2165. https://doi.org/10.4319/lo.2014.59.6.2150

Cao, X. X., Wu, P., Zhou, S. Q., Han, Z. W., Tu, H., \& Zhang, S. (2018). Seasonal variability of oxygen and hydrogen isotopes in a wetland system of the Yunnan-Guizhou Plateau, southwest China: a quantitative assessment of groundwater inflow fluxes. Hydrogeology Journal, 26(1), 215-231. https://doi.org/10.1007/s10040-017-1635-8

Chen, K., Sun, L. H., \& Tang, J. (2020). Hydrochemical differences between river water and groundwater in Suzhou, Northern Anhui Province, China. Open Geosciences, 12(1), 1421-1429. https://doi.org/10.1515/geo-2020-0203

Chen, L. W., Gui, H. L., \& Yin, X. X. (2008). Composing characteristic of hydrogen and oxygen stable isotopes and tracing of hydrological cycle. Journal of China Coal Society, 30(10), 1107-1111 (in Chinese).
Craig, H. (1961). Isotopic variations in meteoric waters. Science, 133(3465), 1702-1703.

https://doi.org/10.1126/science.133.3465.1702

Dansgaard, W. (1964). Stable isotopes in precipitation. Tellus, 16(4), 436-468.

https://doi.org/10.1111/j.2153-3490.1964.tb00181.x

Delavau, C. J., Stadnyk, T., \& Birks, J. (2011). Model based spatial distribution of oxygen-18 isotopes in precipitation across Canada. Canadian Water Resources Journal, 36(4), 313-330. https://doi.org/10.4296/cwrj3604875

Gat, J. R. (1996). Oxygen and hydrogen isotopes in the hydrologic cycle. Annual Review of Earth and Planetary Sciences, 24(1), 225-262. https://doi.org/10.1146/annurev.earth.24.1.225

Gibbs, R. J. (1970). Mechanisms controlling world water chemistry. Science, 170(3962), 1088-1090. https://doi.org/10.1126/science.170.3962.1088

Gorman, J. W. (1976). Optimal subset selection-multiple regression, interdependence and optimal network algorithms. Technometrics, 18(2), 239-240.

https://doi.org/10.1080/00401706.1976.10489432

He, S., \& Li, P. (2019). A MATLAB based graphical user interface (GUI) for quickly producing widely used hydrogeochemical diagrams. Geochemistry, 80(4) 125550.

https://doi.org/10.1016/j.chemer.2019.125550

Jalali, M. (2005). Major ion chemistry of groundwaters in the Bahar area, Hamadan, western Iran. Environmental Geology, 47(6), 76-772. https://doi.org/10.1007/s00254-004-1200-3

Jeff, B. L. (2015). Spatial distribution of $\delta 2 \mathrm{H}$ and $\delta 18 \mathrm{O}$ values in the hydrologic cycle of the Nile Basin. Journal of Arid Land, 7(2), 133-145. https://doi.org/10.1007/s40333-014-0078-5

Ke, Z. J., Zhang, P. Q., Dong, W. J., \& Wang, J. (2009). An application of optimal subset regression in seasonal climate prediction. Chinese Journal of Atmospheric Sciences, 33(5), 994-1002 (in Chinese).

Kuang, X., Luo, X., Jiao, J. J., Liang, S., Zhang, X., Li, H., \& Liu, J. (2019). Using stable isotopes of surface water and groundwater to quantify moisture sources across the Yellow River source region. Hydrological Processes, 33(13), 1835-1850. https://doi.org/10.1002/hyp.13441

Kumar, A., Sanyal, P., \& Agrawal, S. (2019). Spatial distribution of $\delta^{18} \mathrm{O}$ values in river water in the Ganga River Basin: Insight into the hydrological processes. Journal of Hydrology, 571, 225-234. https://doi.org/10.1016/j.jhydrol.2019.01.044

Lee, H., Lee, D. J., \& Kwon, H. (2018). Development of an optimized trend kriging model using regression analysis and selection process for optimal subset of basis functions. Aerospace Science and Technology, 77, 273-285.

https://doi.org/10.1016/j.ast.2018.01.042

Nwankwoala, H. O., Amadi, A. N., Oborie, E., \& Ushie, F. A. (2014). Hydrochemical Factors and correlation analysis in groundwater quality in Yenagoa, Bayelsa State, Nigeria. Applied Ecology and Environmental Sciences, 2(4), 100-105. https://doi.org/10.12691/aees-2-4-3

Ogrinc, N., Kocman, D., Miljevic, N., Vreca, P., Vrzel, J., \& Povinec, P. (2018). Distribution of $\mathrm{H}$ and $\mathrm{O}$ stable isotopes in the surface waters of the Sava River, the major tributary of the Danube River. Journal of Hydrology, 585, 365-373. https://doi.org/10.1016/j.jhydrol.2018.08.024

Piper, A. M. (1944). A graphic procedure in the geochemical interpretation of water analyses. Eos, Transactions American Geophysical Union, 25(6), 914-928.

https://doi.org/10.1029/TR025i006p00914 
Prada, S., Cruz, J. V., \& Figueira, C. (2016). Using stable isotopes to characterize groundwater recharge sources in the volcanic island of Madeira, Portugal. Journal of Hydrology, 536, 409425. https://doi.org/10.1016/j.jhydrol.2016.03.009

Prasanna, M. V., Chidambaram, S., Gireesh, T. V., \& Ali, T. V. J. (2011). A study on hydrochemical characteristics of surface and sub-surface water in and around Perumal Lake, Cuddalore district, Tamil Nadu, South India. Environmental Earth Sciences, 63(1), 31-47. https://doi.org/10.1007/s12665-010-0664-6

Qian, H., Li, P., Wu, J., \& Zhou, Y. (2013). Isotopic characteristics of precipitation, surface and ground waters in the Yinchuan Plain, northwest China. Environmental Earth Sciences, 70(1), 5-70. https://doi.org/10.1007/s12665-012-2103-3

Qian, H., Wu, J., Zhou, Y., \& Li, P. (2014). Stable oxygen and hydrogen isotopes as indicators of lake water recharge and evaporation in the lakes of the Yinchuan Plain. Hydrological Processes, 28(10), 3554-3562. https://doi.org/10.1002/hyp.9915

Singh, G., Rishi, M. S., Herojeet, R., Kaur, L., \& Sharma, K. (2020). Evaluation of groundwater quality and human health risks from fluoride and nitrate in semi-arid region of northern India. Environmental Geochemistry and Health, 42, 18331862. https://doi.org/10.1007/s10653-019-00449-6

Sun, C. J., Li, X. G., Chen, Y. N., Li, W. H., Stotler, R. L., \& Zhang, Y. Q. (2016). Spatial and temporal characteristics of stable isotopes in the Tarim River Basin. Isotopes in Environmental and Health Studies, 52(3), 281-297. https://doi.org/10.1080/10256016.2016.1125350

Sun, L. H., Gui, H. R., \& Chen, S. (2010). Application of minitab to identification of inrush water sources in Wanbei mining area. Coal Science and Technology, 38(2), 104-107 (in Chinese).

Terzer, S., Wassenaar, L. I., Araguás, A. L. J., \& Aggarwal, P. K. (2013). Global isoscapes for $\delta^{18} \mathrm{O}$ and $\delta^{2} \mathrm{H}$ in precipitation: improved prediction using regionalized climatic regression models. Hydrology and Earth System Sciences, 17(11), 47134728. https://doi.org/10.5194/hessd-10-7351-2013

Tiri, A., Belkhiri, L., \& Mouni, L. (2018). Evaluation of surface water quality for drinking purposes using fuzzy inference sys- tem. Groundwater for Sustainable Development, 6, 235-244. https://doi.org/10.1016/j.gsd.2018.01.006

Tóth, J. (1999). Groundwater as a geologic agent: an overview of the causes, processes and manifestations. Hydrogeology Journal, 7(1), 1-14. https://doi.org/10.1007/s100400050176

Tran, D. A., Tsujimura, M., Vo, L. P., Nguyen, V. T., Nguyen, L. D., \& Dang, T. D. (2019). Stable isotope characteristics of water resources in the coastal area of the Vietnamese Mekong Delta. Isotopes in Environmental and Health Studies, 55(6), 566-587. https://doi.org/10.1080/10256016.2019.1673746

Wang, Q., \& Yang, Z. M. (2016). Industrial water pollution, water environment treatment, and health risks in China. Environmental Pollution, 218, 358-365.

https://doi.org/10.1016/j.envpol.2016.07.011

Wet, R. F., West, A. G., \& Harris, C. (2020). Seasonal variation in tap water $\delta^{2} \mathrm{H}$ and $\delta^{18} \mathrm{O}$ isotopes reveals two tap water worlds. Scientific Reports, 10, 13544. https://doi.org/10.1038/s41598-020-70317-2

Wu, J., Li, P., Qian, H., Duan, Z., \& Zhang, X. (2014). Using correlation and multivariate statistical analysis to identify hydrogeochemical processes affecting the major ion chemistry of waters: Case study in Laoheba phosphorite mine in Sichuan, China. Arabian Journal of Geosciences, 7(10), 3973-3982. https://doi.org/10.1007/s12517-013-1057-4

Wu, J., Li, P., Wang, D., Ren, X., \& Wei, M. (2020). Statistical and multivariate statistical techniques to trace the sources and affecting factors of groundwater pollution in a rapidly growing city on the Chinese Loess Plateau. Human and Ecological Risk Assessment, 26(6), 1603-1621. https://doi.org/10.1080/10807039.2019.1594156

Zhang, B., Song, X. F., Zhang, Y. H., Han, D. M., Tang, C. Y., \& Yang, L. Y. (2015). The relationship between and evolution of surface water and groundwater in Songnen Plain, Northeast China. Environmental Earth Sciences, 73(12), 8333-8343. https://doi.org/10.1007/s12665-014-3995-X

Zheng, S. H., Hou, F. G., \& Ni, B. L. (1983). Hydrogen and oxygen stable isotopes of precipitation in China. Chinese Science Bulletin, 28(13), 801-806 (in Chinese).

https://doi.org/10.1360/csb1983-28-13-801 